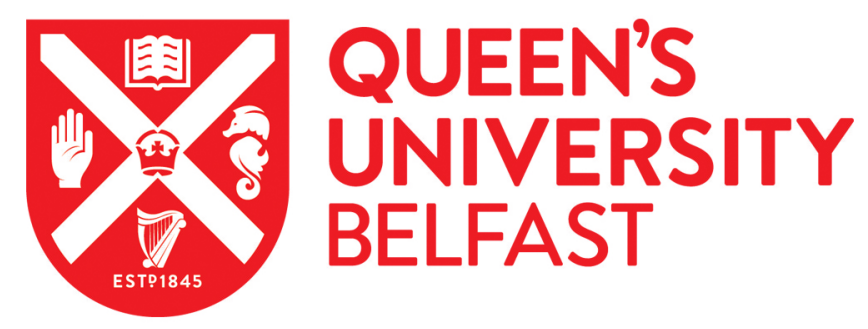

\title{
History Begins: Shareholder Value, Accountability and the Virtuous State
}

O'Kelly, C. (2009). History Begins: Shareholder Value, Accountability and the Virtuous State. Northern Ireland Legal Quarterly, 60(1), 35-50.

Published in:

Northern Ireland Legal Quarterly

Document Version:

Publisher's PDF, also known as Version of record

Queen's University Belfast - Research Portal:

Link to publication record in Queen's University Belfast Research Portal

Publisher rights

๑ 2013 Northern Ireland Legal Quarterly

\section{General rights}

Copyright for the publications made accessible via the Queen's University Belfast Research Portal is retained by the author(s) and / or other copyright owners and it is a condition of accessing these publications that users recognise and abide by the legal requirements associated with these rights.

Take down policy

The Research Portal is Queen's institutional repository that provides access to Queen's research output. Every effort has been made to ensure that content in the Research Portal does not infringe any person's rights, or applicable UK laws. If you discover content in the Research Portal that you believe breaches copyright or violates any law, please contact openaccess@qub.ac.uk. 

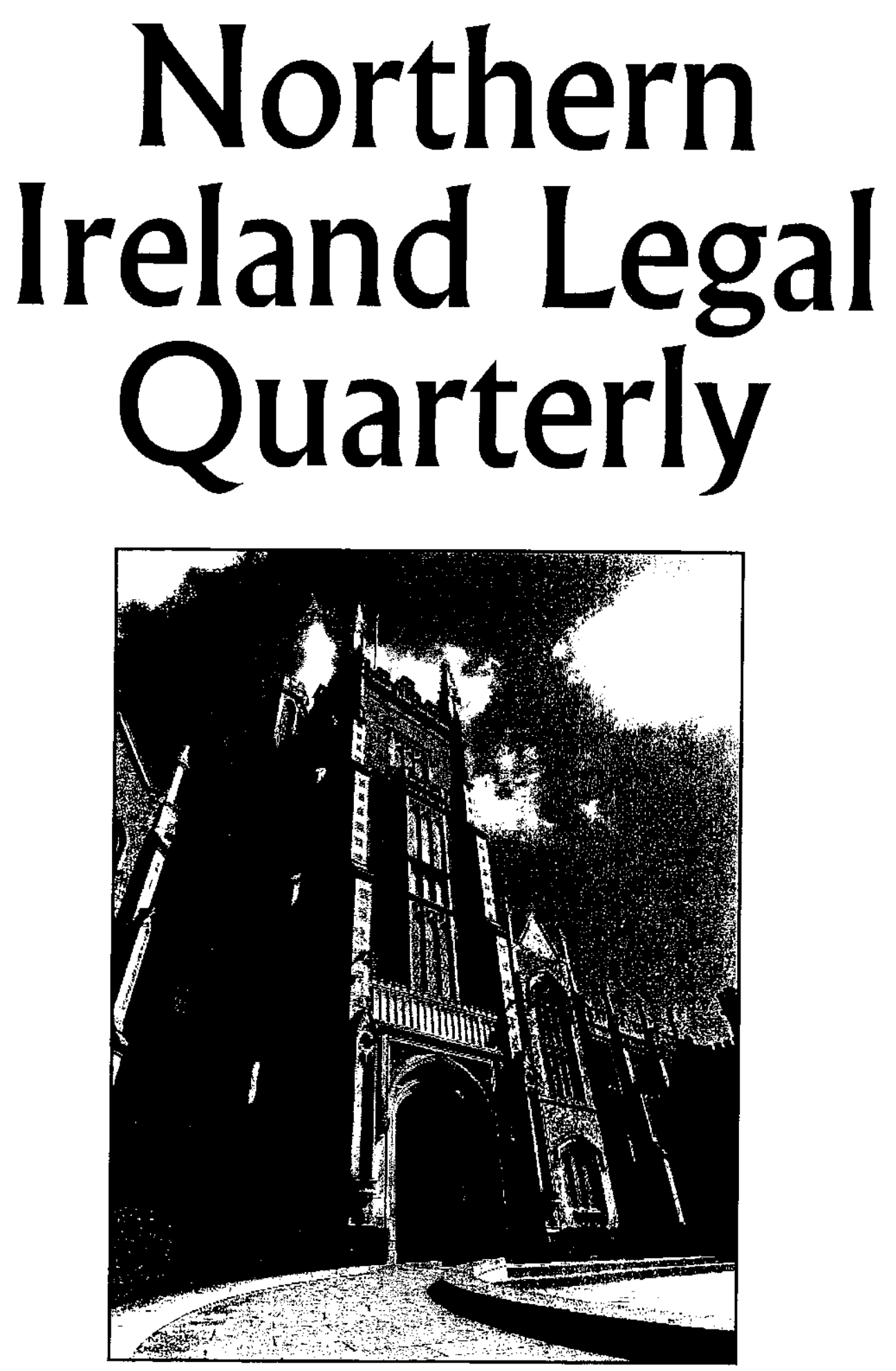

Volume 60 Number 1 Spring 2009

Special Issue on Corporate Governance 


\title{
Northern Ireland Legal Quarterly
}

Editor:

\author{
Professor Sally Wheeler
}

Production editor:

Marie Selwood

The editor invites submission of material with a view to publication in the Quorterly. Articles of any length will be considered for publication, but should not normally exceed 10,000 words. See "Notes for contributors" (inside back covet).

Published four times a year by the School of Law, Queen's University Belfast.

\section{CONTACTS}

Please address editorial correspondence to:

Professor Sally Wheeler, School of Law, Queen's University, Belfast BT7 1NN

tel 02890973468

s.wheeler@qub.ac.uk

For subscriptions, please contact:

Law Office, School of Law, Queen's University; Belfast BT7 1NN

tel 02890973597

fax 02890973376

law.office@qub.ac.uk

Subscription rate: $£ 85$ per year.

Please address other cortespondence, including advertising enquiries, to:

Marie Selwood, Production Editor NILQ, 33 Baddlesmere Road,

Whitstable, Kent CT5 2LB

tel 01227770189

marieselwood@btinternet.com

Advertising rates:

- full page: $f_{1} 175$

- half page: $\mathfrak{f}^{100}$

- quarter page: $£ 75$

- inserts: $f_{175}$ (with surcharge for additional weight where applicable)

\section{NILQ BACK ISSUES}

2008 (vol. 59): enquiries to Law Office, QUB (see details above).

2004-07 (vols 55-58): encuiries to Marie Selwood (see details above).

1936-2003 (vols 1-54): HeinOnline www heinonline.org.

(C) School of Law, Queen's University Belfast, Copyright in material in the Nortbern Ireland Legal Quarterly is assigned to the publisher but permission will normally be granted to republish elsewhere with due acknowledgment.

Cover photograph: QUB Media Services.

ISSN 0029-3105 
Northern Ireland Legal Quarterly Volume 60 Number 1

\title{
Contents
}

\author{
Special Issue on Corporate Governance
}

This special issue is based on papers presented at a colloquimm beld at Queen's University Belfast on 17-18 September 2008 entitled "The Globalization of Corporate Governance? Reform pressures and processes in an era of financial crises" which assessed the current state of global regulatory practice and identified future challenges and possible responses to these. The colloguitm was organised under the aegis of the Law Sibool's ESRC-funded project, "Regnlatory Regine Cbange in Financial Markets: the case of SarbanesOxley" based at the Institute of Governance. See wnw.qub.ac.uk/sox/.

\section{Financialization and corporate governance}

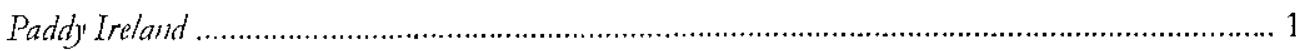

History begins: shareholder value, accountability and the virtuous state Ciarán O'Kelly'

Non-executive directors and corporate governance

Sally Wheeler

A global framework for management commentary disclosure?

Charlotte Villiers

The end of "comply or explain" in UK corporate governance?

Marc T Moore

Governance reform pressures and processes in the NHS in Scotland 


\section{HEINONLINE}

Citation: 60 N. Ir. Legal Q. 352009

Content downloaded/printed from HeinOnline (http://heinonline.org)

Wed Jul 17 09:49:42 2013

-- Your use of this HeinOnline PDF indicates your acceptance of HeinOnline's Terms and Conditions of the license agreement available at http://heinonline.org/HOL/License

-- The search text of this PDF is generated from uncorrected OCR text.

-- To obtain permission to use this article beyond the scope of your HeinOnline license, please use:

https://www.copyright.com/ccc/basicSearch.do? \&operation $=$ go\&search Type $=0$ \&lastSearch $=$ simple \&all $=$ on \&titleOrStdNo=0029-3105 
NILQ 60(1): $35-50$

\section{History begins: shareholder value, accountability and the virtuous state \\ Ciarán O'Kelly}

Queen's University Belfast

\section{Introduction}

Tnlike most previous recessions, the economic shock at the heart of the global financial crisis from 2007 onwards was endogenous to the corporate form rather than external to it. While the crisis was, in immediate terms, brought on by the end of a property bubble - a more or less traditional end to a speculative frenzy in the United States and some parts of Western Europe $\mathrm{e}^{1}$ - the paradigm-shifting moment at the heart of the financial crisis saw a series of structural failings brought to a head and their supporting hypotheses - that markets are more or less perfectly efficient in their use of information and that, as a result, markets will distribute societal resources in the least wasteful manner possible - revealed as seriously flawed.

What of the corporate form itself? How are we to understand the company in the midst of growing evidence about the structural vulnerability of financialised capitalism to instability? This paper addresses the shareholder value paradigm as an accountability claim for the corporation. Shareholder value mechanisms - predominantly in the form of incentives to align the interests of management with those of shareholders - are regarded as a more efficient means for corporate governance than external regulation or direct shareholder control. Nevertheless, any accountability claim must be rooted in a sense of the virtues that legitimate the claims. Without those virtues, mechanisms of control would simply be free-floating uses of force by one section or another in society.

In large part, we must explore the gap between the portrayal of the company as an accountability vehicle and the evidence for the accountability claims made regarding the company. Moreover, we must understand these accountability claims, not as simple descriptions of mechanisms (and the virtues that underpin them), ${ }^{2}$ but as claims on society: claims for virtuous corporate governance are also claims over societal resources and claims

1 For a discussion of a long series of crashes, see $\mathrm{C} P$ Kindleberger and R Z Mliber, Matmas, Panics and Crashes: A bistory of financial crises 5th edn (Basingstoke: Palgrave Nacmillan 2005).

2 For a discussion of accountability mechanisms and virtues, sec M Bovens, "lwo concepts of accountabilit." (paper prescrted at the Kettering Symposium on Accountabilit, Kittering Institution, Dayten $\mathrm{OH}, 2(108)$. I use the term "virtue" simply to denote the moral content that must exist if some social arrangement is to legitimate. A prolonged discussion, sav, of the distinction betuicen virtues and other normative forms is beyond the scope of this paper. 
to freedom from interference. Accountability in this sense is as much about the terms of a virtuous society as it is about specific mechanisms and technologies of control.

For accountability mechanisms to be legitimate, they must take place in the context of a specific moral community. ${ }^{3}$ Arguments that, say, efficiency ought to be taken as a worthwhile goal for a society, can only have force in the context of arguments that provide it with worth and meaning. As such, we have to see arguments over shareholder value as arguments on behalf of shareholders against other possible claimants for corporate resources. Legitimacy has to emerge from the formulations of a moral community either by reconstructing the boundaries of the community or by placing new claims in the context of existing norms. Of course, normative claims made against already existing norms are subject to evidence and are testable.

The corporation is held up by agency theorists as an accountability vehicle. Accountability is taken, at least by shareholder value theorists, to be the very raison d'etre of the company. How are we to understand this sense of accountability? Patently, the successful production of the more action-oriented orders of accountability within the modern company has not stabilised market economies. It may, however, be wrong to say that it has not served shareholders. It is possible that shareholders have been, at least during periods of economic growth, content to trade on the basis of competition between companies to innovate and to produce news that would be pleasing to the markets.

My purpose for the remainder of this paper is to examine three claims for shareholder value. Taken together, these claims, for the company as an accountability vehicle that ties managers to shareholders, rely on wider norms for their legitimation. They ought to be seen as arguments about the shape of society rather than as simply being about the corporate form. Accountability in these terms, is a matter of the struggle for resources: it is a political device. Furthermore, the shareholder value framework is tied to testable claims about how society works. These claims, it seems, either describe a company that never existed or one that no longer exists. Certainly, the financialisation of capitalism has led to the rise of the "postmodern" company, oriented towards the production of spectacles for stock market consumption rather than towards production in any traditional sense. I return to this issue below. First, I address the three claims for the company as a shareholder valueoriented accountability vehicle.

\section{The shareholder value paradigm}

The shareholder value hypothesis is one of the key hypotheses of the financialised capitalism of the 1980 s onwards. ${ }^{4}$ Seeming at times like an "all-purpose justification" for every strategic management decision, ${ }^{5}$ the rise of the shareholder value paradigm, in

3 For a Smithian discussion of accountability formulated in moral communities, sce S L Daruall, The Secondperson Standpoint: Morality, respect, and accoumtability (Cambridge, MA: Harvard UP 2006).

4 On financialisation, see J Froud, S Johal, A Leaver and $\mathrm{K}$ Williams, Financialization and Strategy: Narrutre and mimbers (London: Routledge 2006); J Froud, A Leaver and K Williams, "New actors in a financialised cconomy and the remaking of capitalism" (2007) 12 New Political Economy 339-47; J Froud, C Haslam, S Johal and K Williams, "Shareholder value and financialization: consultancy promises, management moves" (2000) 29 Economy and Sociefy 80-110; G R Krippner, "The financialization of the American economy" (2005) 3 Socoecion Re $\nu$ 173-208; T A Kochan, "Beyond financialization: the era ahead" (2008) 30 Comparative Labor Lau' and Polic Journal 89; K Williams, "From shareholder value to present-day capitalism" (2000) 29 Economy and Socien i: E Engelen, "The case for financialization" (2008) 12 Competition and Change 111-19; M Iglictta and A Rebérioux, Corporate Governance Adrift. A rritique of shareholder value (Cheltenham: Eduard Elgar Publishing Ltd 2005): G Jackson, "A new financial capitalism? Explaining the persistence of exit over voice in contemporary corporate governance" (2008) 5 European Management Review 23-6.

5 Froud et al., Financialization and Sirategy, n. 4 above, p. 38. 
scholarship and in the business world, has accompanied a major shift in the level of appropriation of resources by a managerial class. The shareholder value paradigm that served to divert resources even further towards a wealthy financialised class is itself driven by a body of normative claims over how distribution ought to happen in society. These claims underpin a system of accountability claims and mechanisms that reshaped systems of corporate governance oversight in a way that allowed appropriation to take place and destabilised the global financial system on the way. At their core, in other words, the accountability mechanisms of the mainstream corporate governance paradigm - rather than being normatively and ideologically neutral roadmaps to corporate clarity and honesty - are profoundly flawed, albeit influential, political statements that have produced greater inequality in the name of market egalitarianism.

The facts of appropriation are insufficient to explain the appropriation itself. The explanation for why such a massive shift in societal power and wealth happened must lie in a shift in the political foundations of society. The story of financialisation and recent crises is not a story about gangs of "bad apples". It is about the philosophical shifts that took place in the wake of technological and regulatory changes. Although sometimes articulated as mere statements of fact, in other words, it is about ideology.

In their influential study of globalisation, shareholder value and the convergence of company law, Hansmann and Kraakman present the Anglo-American model more or less as a fait accompli, their comparative corporate governance argument proposed that there is "no longer any serious competitor to the view that corporate law should principally strive to increase long-term shareholder value". ${ }^{6}$ Convergence in company law, they argue, ought to enable shareholder-oriented corporate governance mechanisms worldwide, rooted as they ought to be on "a broad normative consensus that shareholders alone are the parties to whom corporate managers should be accountable, resulting from widespread disenchantment with a privileged role for managers, employees, or the state in corporate affairs" This normative consensus, they write, is based on the shareholder value's being "the best means to aggregate social welfare". 7 Agency and contractual corporate theorists draw on a range of conventional "normative" arguments for convergence on shareholder value. Hansmann and Kraakman rely on the most common key defence of shareholder value and of the enabling role that law ought to play in the promotion of shareholder value: that is, that its benefits are a reflection of greater corporate, economic and societal efficiencies. Sitting alongside the efficiency argument many company law theorists defend shareholder value on general democratic or egalitarian arguments. Others rely on an ownership argument: that shareholders, as property owners, ought to get their just deserts, or a varient: that shareholder value arises from residual claims. I will address ownership/residual claims and the democratic/egalitarian arguments for the shareholder value accountability mechanism before moving on to the issue of efficiency.

\section{Claims for shareholder value}

\section{OWNERSHIP AND RESIDUAL CLAIMS}

The ownership argument is, on the face of it, the least persuasive defence of shareholder value. $^{8}$ It is also the most normatively pure argument, in that it does not rely upon the consequences of shareholder value's being enshrined in corporate practice for it to have

6 II Hansmann and R H Kraakman, "The end of history for corporate law" (2001) 89 Georgetoun Lin' Jourmal 439.

7 lbid., p. $4+1$. 8 See L, Stout, "Bad and not-so-bad arguments for sharcholder primacy" (2002) 75 Soutbern Colifornia Law
Revien' 1190. 
force. Rather, such is the force of the ownership argument that, even if shareholder value produced inefficiencies, the argument that property owners ought to receive their just deserts would still hold.

While the application of this argument to corporate governance rests with Milton Friedman, ${ }^{9}$ it, of course, has much deeper foundations in the origins of modern propertyowning capitalism. The idea of ownership is a common refrain in the business world and the media as both providing a moral guide to directors and as an explanation for decisions that have a negative impact on other internal stakeholders or on society at large. ${ }^{10}$

To do otherwise than to orient corporate governance towards shareholders would be to appropriate "other people's money". ${ }^{11}$ Alternatively, as the White Paper on British company law in the run-up to the Companies Act 2006 had it, it is "crucial to effective corporate governance that the owners of the company hold the directors to account for the company's performance". ${ }^{12}$ Ownership in these cases is valuable in itself and has positive consequences for society as a whole (through effective corporate governance).

In some ways shareholder value is a throwback to the pre-Berle and Means ownership model where ownership was regarded as an uncomplicated matter. ${ }^{13}$ The shareholder value paradigm resurrects the owner (literally or in the residual claimant guise), but in a context where the corporate princes are no longer connected in a tangible way to their propertyowning masters. Unfortunately, the ownership argument is neither normatively nor empirically tenable. On the empirical claims, it is unclear how we ought to view shareholders as owners in any meaningful sense. Share ownership does not, as a number of people have pointed out, confer ownership of a company in the same way that one might own, say, a car or a house. Shareholders do not have access to the company's assets. Nor does company law confer much more than limited rights of control and governance. ${ }^{1+}$ Neither would greater shareholder power in response to their supposed ownership rights be necessarily desirable. ${ }^{15}$ Company law does not confer any sensible ownership claim on shareholders,

9 M Friedman, "The social responsibility of business is to increase its profits" (1970) 122 (13 September) New" Sork Times Magerine 32-3; for a wider discussion of the place of Friedman's defence of shareholder value in his overall Hayckinn framew'ork, see R Chen and J Hanson, "The illusion of lau" the legitimating schemas of modern policy and corporatc law" (2004) 103 . Michigan Lu' Revien 1-149; for a discussion placing Friedmanite and Hayekian theories in the context of the development of the Brtish corporate economy, sec L Talbot, Critical Company Law 1st edn (London: Routledge-Cavendish 2007), pp. $119 \mathrm{ff}$.

10 Very often the frame serves both purposes. See e.g. Channel Four New's, "Jon Snow interviews John Varley, Chief Executive of Barclays Bank", 14 January 2009, www.channel4.com/news/artucles/ business_money/extended+interview+john+varley/2903807 (last accessed 3 February 2009).

11 Talk of "other people's money" draws from $\lambda$ dam Smith's discussions of the joint stock company: For one discussion see D G Bard and M T Henderson, "Other people's money" (2008) 60 Stanford Law Review 1309-44.

12 Department of Trade and Industry, Modernising Company Law, White Paper (London: DTI 2002), para. 2.37; for a discussion, see R Goddard, “Modernising Company Law': the Government's White Paper" (2003) 66 Modern Law Revien 402-24: For a recent discussion, see Department for Business Enterprise and Regulator! Reform, Implementation of the Directive on the Exerrise of Certain Rights of Shareholders in Listed Companies: $A$ consultation document (London: BERR 2008), p. 55: "Principals need to effectively monitor and to some extent control their agents to ensure that managers are acting in the best interests of the company's ouners and that the scope for moral hazard is minimised. . The proposed Directive aims to lower agency costs so that sharcholders can engage more effectively and cnsure the companies that they own are mote efficient."

13 L. Dallas, "Two models of corporate governance: beyond Berle and Means" (1988) 22 University of .Matugan Journal of Law Reform 12-116.

14 Sec L E Mitchell, Corporate Irresponsibility: America's newest export (Ncw Haven: Yale L'1' 2001), pp. 119ff; Sitsut, "Bad and not-so-bad", n. 8 above, pp. $1190 \mathrm{ff}$.

15 L $A$ Stout. "The mythical benefits of shareholder control" (2007) 93 l'irginia Law Review 789-809. 
although corporate governance à la agency theory is obviously replete with expectations about shareholder entitlements. ${ }^{16}$

Nevertheless, the ownership argument founders on the fact that real shareholder rights are only as extensive and sometimes less so than those of, for instance, creditors. Options theory, Stout tells us, suggests that "it is not only misleading to say that dispersed shareholders 'own' a public corporation, but that it is even questionable, from an economic perspective, to say that a single controlling shareholder 'owns' a closely held firm after the firm has issued debt". ${ }^{17}$ After all, a creditor will have a greater call on the company's assets in the event of the company being wound up. It seems more sensible, as Stout argues, to say that the shareholder has traded a call-option on the company than to say that they "own" it.

The share as a commodity to be bought or sold has long loosened the tie between companies and their members. ${ }^{18}$ In this light, the shareholders' part of the deal has resided for over a century not in the governance of the firm, but in the trading of shares as "autonomous forms of property". ${ }^{19}$ It goes without saying that technological and regulatory changes have seen this commodification of the share intensify in the last twenty-five years. Whereas, as recently as the early 1980s, the majority of shares on the London Stock Exchange (LSE) were in private hands, that had fallen to 12.8 per cent by 2006. With foreign (presumably largely institutional) investors owning 60 per cent of stock, private financial enterprises own 44.4 per cent. That is, almost 75 per cent of domestically held stock is in the hands of institutional shareholders. ${ }^{20}$ Shareholders, in other words, have less and less resembled owners in any conventional sense even as shareholder value rhetoric intensified.

Admittedly, the ownership argument in its Friedmanite sense is now regarded as outdated by many contractarian corporate theorists. ${ }^{21}$ For "nexus of contracts" theorists, ${ }^{22}$ shareholders ought not to be regarded as owners, but as "residual claimants, whose claims over corporate resources are not realisable until all outstanding contracts

16 For a discussion of expectations beyond law, see $S$ Wiorthington, "Shares and sharcholders: property, power and entutlement (part 1)" (2001) 22 Company Lomyer 258-66; S Worthington, "Shares and shareholders: property, power and entitlement (part 2)" (2001) 22 Compan!' Laujer 307-14.

17 Stout, "Bad and not-so-bad", n. 8 above, p. 1192.

18 P Ireland, "Capitalism without the capitalist: the joint steck company share and the emergence of the modern doctrine of separate corporate personalicy" (1996) 17 Josrnal of Legal History 66-7.

19 Ibid., p. 42; see also Mitchell's account of the risc of the American shareholding economy, rooted as it was in the promotion of speculative share ownership, not in ownership as such: L E Mitchell. The Speculation Economy (San Francisco: Berrett-Koehler Publishers 2007).

20 Federation of European Securities Exchanges, Share Ownership Structure in Europe (Paris: Federation of European Securities Exchanges 2008), p. 83.

21 S Bainbridge, "In defense of the shareholder wealth maximization norm: a reply to Professor Green" (1993) 50 W'ashington and Lee Law Revien' $1+27$.

22 On the corporation as a nexus of contracts, see F Easterbrook and D Fischel, The Economic Structure of Corporate Lan (Cambridge ML: Harvard UP 1991); F Easterbrook and D Fischel, "The corporate contract" (1989) 89 Columbia Law Reriew" 1+18-48; L Kornhauser, "The nexus of contracts approach to corporations: a comment on Easterbrook and Fischel" (1989) 89 Columbia Law Review 14+9-60; K I Itvak. "Frank Easterbrowk and Danicl Fischel" in L Cohen and J Wright (eds), Pioneers of Law and Economics (Cheltenham: Fduard Figar 2008): $M \wedge$ Eisenberg, "The conception that the corpotation is a nexus of contracts, and the dual nature of the firm" (1999) 24 Journal of Corporation Low 819-36; E F Fama and M C Jensen, "Separation of ownership and control" (1983) 26 Jourmal of Law and Economics 301-25; O Hart, "An economist's perspective on the theory of the firm" (1989) 89 Columbia Law Rerrew 1757-74, W'Bratton, "The "nexus of contracts" corporation: a critical appraisal" (1989) 74 Cormel/ Lan' Retien' 407-65. 
have been fulfilled". 23 "The contract structures of organizations limit the risks undertaken by most agents by specifying either fixed payoffs or incentive payoffs", Fama and Jensen tell us, so "the residual risk - the risk of the difference between stochastic inflows of resources and promised payments to agents - is borne by those who contract for the rights to net cash flows". 24 So shareholders, as residual claimants, deserve to have their interests attended to because of their weak position, relative to other stakeholders, in the distribution of assets from the firm.

Nevertheless, it is unclear how this takes us much further on from the Friedmanite ownership frame. If, as Ireland puts it, under the residual claims frame, shareholders "own not 'the company' but 'the capital,' the company itself having been spirited out of existence", 25 we are still left with many of the same problems.

For a start, "it is essential to recognize that the only time that corporate law comes close to treating shareholders like residual claimants is when the firm is actually in bankruptcy." 26 Moreover, as with the ownership argument, the residual claims argument is not aimed at empowering shareholders in concrete ways. Rather, it seeks to have managers simply attend to shareholder value in making their decisions. This is quite a different thing, say, to enforcing a dividend policy. Instead of seeking specific contractual or quasi-contractual rights, the shareholder value paradigm simply seeks the acceptance of an "ought" statement: that directors ought to have shareholders in mind when they act. Given this, the residual claims argument, on these terms, does not give us good reasons for privileging shareholders over stakeholders in a similar position when it comes to corporate governance.

Any normative appeal to the ownership or residual claimant arguments to claim desert for shareholder primacy is bound up with these empirical flaws. First, as we have seen, given the, at times, narrow range of relationships within the corporate architecture, it is difficult to ascertain why shareholders ought to be privileged. Second, however, shareholding ownership can in no way be regarded as sovereignty. Rather, shareholder value involves a claim to a strange sort of delegated sovereignty. The agency relationship as described by the advocates of shareholder value, with agents acting on the principal's behalf (though not, it seems, at their behest), relies on agents presuming the principal's interests, as they develop an agenda for the company's actions.

Finally, rather than setting out a norm for shareholder sovereignty arising from share ownership, shareholder value seems to entail an especially inegalitarian version of property norms, especially in terms of shareholder value's allowing directors to act "without regard to the consequences to others". 27 This Hayekian conceit leaves directors citing their duties to shareholders as a defence for their actions and shareholders being so distanced from corporate actions that they cannot be held responsible for corporate actions either. The

23 On residual claims, see E F Fama and M C Jensen, "Agency problems and rusidual claims" (1983) 26 Journal of Law and Economics 327-49; B Klein, "Contracting costs and residual claims: the separation of ownctship and control" (1983) 26 Journal of Law and Economics 367-74; J Macey, "Economic analysis of the various rationales for making shareholders the exclusive beneficiaries of corporate fiduciary dutics" (1991) 21 Sretson Lan Reriew 23-44; A K Sundaram and A C Inkpen, "The corporate objective rcvisited" (2004) 15 Organization Science 350-63; O E Williamson, "Organization form, residual claimants, and corporate control" (1983) 26 Journal of Lau' and Economics 351-66; F H Easterbrook and D R Fischel, "Voting in corporate law" (1983) 26 Journal of Law and Economics 395-427; Eisenberg, "Conception", 1. 22 above; Fama and Jensen, "icparation", 14. 22 above; Hansmann and Kraakman, "The end of history", n. 6 above, p. 449.

24 Fama and Jensen, "Agency problems", 11. 23 above, p. 328; sce also Maces, "Economic analysis", u. 23 above.

25 P lreland, "Company law and the myth of shareholder ounership" (1999) 62 Modern Law Reivew 33.

26 Stout, "Bad and not-so-bad", n. 8 above, p. 1193.

27 Nitchell, Corporate Irresponsibility, n. 14 above, p. 122. 
corporate person, as Elizabeth Wolgast writes, is not "like using a stick to reach farther than the length of one's arm". ${ }^{28}$ While Wolgast argues that "if deliberation and choice are not wedded to doing - which is to say, if the person who decides is not the one who acts - there is strong reason for arguing a person's non-responsibility", 29 the company is arguably even worse than she describes. The same person is "doing the deciding" and "doing the doing" but, as the shareholder value paradigm has it, the decisions really belong to someone else. Moreover, that "someone else" is very often the manager themselves, at least where they are a beneficiary of stock options designed to align their interests with those of other shareholders. ${ }^{30}$ Given this, in terms of any sensible conception of delegation responsibility, the corporation is a fiction within a fiction: it separates out responsibility to the point where it simply does not exist. So, it is a vehicle for accountability that contains few if any of the conventional characteristics or responsibilities associated with property holding. In this light, the claim for shareholder value, articulated as a pure call on the moral attachment to just deserts is actually, if anything, a liberation from accountability as conventionally understood.

\section{DemoCRatic/EGalitarian arguments}

A second line of legitimating argument in underpinning shareholder value is the idea that it is ultimately a democratic and egalitarian device. This argument has two main flavours. In one, proponents of shareholder value point to the extension of shareholding through pension funds, privatisation drives and other means as taking that share ownership is now in many ways public ownership and, given that, shareholder value involves a democratising of capitalism. As Hansmann and Kraakman say, with widespread share ownerships,

no longer do labor and capital constitute clearly distinct interest groups in society. Workers, through share ownership, increasingly share the economic interests of other equity-holders. Indeed, in the United States, union pension funds are today quite active in pressing the view that companies must be managed in the best interests of their shareholders. ${ }^{31}$

Indeed, not only is this shift virtuous in itself. It also places obligations of care on directors that bring them back to the residual claimants argument, though now with added moral force. As Peter Brabeck-Letmathe, CEO of Nestle put it: "Should we fail as a business, it is [shareholders] retirement savings which are destroyed, so they're the primary stakeholders of our company." 32 This works on a practical level because the development of layers of agents, it is supposed, will lead to the interests of "ultimate owners" being attended to by the rise of the professional institutional investor. For Hansmann and

28 E Wolgast, Ethics of an -1rtificial Person: Lost responsibility in professions and organizations (Stanford: Princeton UP, 1992), p. 65. Wolgast is arguing about the Hobbesian artificial person, but in many ways the modern corporate person falls within the general ambit of Hobbes's concerns.

29 Ibid.

30 As Monks points out, one survey revealed that, by $1992,97 \%$ of all stock options went to the top 15 individuals in each firm: $\mathrm{R} \mathrm{A} \mathrm{Monks.} \mathrm{"Redesigning} \mathrm{corporate} \mathrm{governance} \mathrm{structures} \mathrm{and} \mathrm{systems} \mathrm{for} \mathrm{the}$ twenty first century" (2001) 9 Corporate Gotername: $A$ in infernational retuew $1+3$.

31 Hansmann and Kraakman, "The end of history", w. 6 above, p. 452. 32 P Brabeck-I etmathe, “Creating Shareholder Value and Corporate Responsibility: Competing Guals?”, speech
given at London Business School, 2006. 
Kraakman, the agency relationship driving investment funds will encourage greater shareholder activism in enforcing shareholder value claims on corporations. ${ }^{33}$

On the rise of the pension-fund democracy, the shareholder value argument relies on three core ideas: first, that shareholdings have truly become more extensive in a meaningful way; second, that shareholder value brings benefits to a greater range of people through this extension of shareholding; and, third, to a lesser degree for our purposes here, that the institutional infrastructure around this shareholding democracy is such that the promotion of shareholder value is locked into the system.

As a normative proposition, it scarcely matters whether or not the rise of the institutional investor actually facilitates a greater attachment to shareholder value than would otherwise be the case, ${ }^{34}$ though it might be relevant to a wider discussion about efficiency. On the whole, though, the first two claims - that shareholdings are more extensive throughout society and that benefits accrue to increasingly indirect shareholders - ought to be met with some scepticism.

For a start, while the benefits of increased private pension and equity holdings may indeed accrue to a wider portion of the popularion, the benefits are disproportionately concentrated among the already better-off. ${ }^{35}$ Indeed, while median household income for the poorest 20 per cent of households in the United States rose by 14 per cent between 1980 and 2007, the incomes of the wealthiest 5 per cent of households rose by 72 per cent. ${ }^{36}$ Measured through tax returns and including all capital gains, the top 1 per cent of households had seen their share of all American household income rise to 20 per cent of

33 Hansmann and Krakman, "The end of history", n. 6 above, p. 453; this argument is current in the UK"s corporate governance codes where it is imagined that the "enlightened" character of "enlightened shareholder value" will arise from the interventions of institutional investors. See linancial Reporting Councul, The Combened Code on Corporate Governance (London: Financial Reporting Council 2008), s. 2: Institutunal Shareholders' Committee, The Responsibilities of Institutional Sharebolders and Agents - Statement of principles (London: Institutional Shareholders' Committee 2007).

34 Evidence is mixed, with some scholars and policymakers sceung potential in institutuonal shareholders (scc A Shleifer and R W Vishny, "Large shareholders and corporate control" (1986) 94 Journal of Political Eionomy 461-88; Financial Reporting Council, Combined Code, n. 33 above, s. 2; Institutional Shareholders' Committec, Responsibilities, 11. 22 above) and others expressing some scepricism; for a more scepucal approach, sec J Armour, S Deakin and S J Konzelmann, "Shareholder primacy and the trajectory of L'K corporate governance" (2003) 41 British Journal of Industrial Relations 5 t6, who argue that institutional investors with large portfolios across a range of firms in any market "do not benefit from short-term gains achieved through the operation of the market for corporate control. They are likely to take the view that takeover bids that result in substantial gains for target shareholders bring them little gain if, over time, they do not produce enhanced returns for shareholders in bidder companies, since they will most likely hold equity stakes in both sets of firms."; see also S Gillan and L Starks, "Corporate governance proposals and shareholder actuism: the role of institutional investors" (2000) 57 Jorrnal of Financial Economucs 275-305; S Gillan and L Starks, "Corporatc governance, corporate ownership, and the role of insututional unvestors: a global perspective" (2003) 13 journal of Applied Finance +22; J G Hill, "Visions and revisions of the shareholder" (2000) 48 , American Journal of Comparative Law 39: B R Cheffins, Corporate Ownership and Control: British business transformed (Oxford: OL'P, 2008), pp. 382ff; B Cheffins, "Current trends in corporate governance: going from London to Malan va Toronto" (1999) 10 Duke Journal of Comparative and International Law 13.

35 For a discussion of the distribution of equity and wealth, see $p$ Ireland, "Shareholder prmacy and the distribution of wealth" (2005) 68 Modern Law' Review 58ff.

36 Census Bureau, "Historical income tables - households" at wuw:census.gov/hhes/uww/income/histanc/ h03.IR.huml (last accessed 1 February 2009); see also J McNeil, Changes in Median Housebold Income: 1969 to 1996 Current Population Reports (Washington DC: Census Bureau of the United States 1998); D Wicinburg, .4 Brief Look at Postuar US Income Inequalig: Curremt Population Reports (Washington DC: Census Bureau of the United States 1996). 
the whole by 2007 , with 9 per cent in the hands of the top 0.1 per cent. ${ }^{37}$ The wealth of people in the bottom decile was more or less static in real terms. Although the raw figures are less stark in the UK, the patterns are more or less the same: the financialisation of people's savings through pensions and other vehicles has not been an egalitarian enterprise. $^{38}$ There is neither evidence of progressive redistribution (although there is plenty of evidence of regressive transfers) nor of a "trickle down" of resources, where the kinds of inequality that have developed in the last twenty years prove to be Pareto optimal. ${ }^{39}$ Again, shareholder value theorists' aspirations to defend shareholder value on normative grounds are as untenable as their empirical claims are unsustainable.

As the wave of privatisations and the privatisation of pension contributions transferred vast public savings into the financial markets it is clear that, rather than wealth being redistributed, it is increasingly concentrated among the wealthiest members of society. Of these, financial capitalists have benefited the most. In the USA, the proportion of Wall Street executives (that is, of financialised capitalists) in the ultra-rich income brackets has increased markedly in the past fifteen years. ${ }^{40}$ The transfers seem to have facilitated even greater appropriation by financial elites as an intricate network of fees, bonuses and options replaced the direct relationships between management and production.

In other words, ironically, the core motivator behind shareholder value and agency theory - incentive-based work - did not empower the shareholder. Rather, it simply allowed executives and people throughout the financial chain to divert vast resources to their own pockets. Oversight is unlikely where brokers do not maximise returns either through activism or even through long-term "investment" in a set of shares. Expecting long-term relationships, as policy-makers in the UK do, is quixotic where

many fund managers feel unable to take long-term positions in companies, and so their buy and sell decisions are driven by short-term movements in the share price. The reason for this is that fund managers' performance is scrutinised by their clients (pension and other investment funds) on the basis of quarterly performance statistics. ${ }^{41}$

It is difficult, moreover to discern any shift towards long-term institutional share ownership when, albeit for a variety of complex reasons, share turnover velocity on the LSE was 154

37 Sec A B Atkinson and T Piketry, "Income and wage inequality in the United States (updated to 2006)" (2008), available at htp://elsa.bcrkeley.edu/ -sacz/ (accessed 1 February 2009); this table is an update to " 1 ' Prketty and E Saez, "Income and wage inequality in the United States, 1913-2002" in A B Atkunson and 1 Piketty (cds), Top lucomes Over the Tuentieth Century: 1 contrast between continental European and English-speaking countries (Oxford: OUP 2007), pp. 141-225; and T Piketty and E Saez, "Income inequality in the United States, 1913-1998" (2003) 1:8 Quarterly Journal of Economics $1-39$.

38 See Ireland, "Shareholder primacy", „1. 35 above, pp. 62ff, for a discussion.

39 See e.g. M Aglictta and R Breton, "Financial systems, corporate control and capital accumulation" (2001) 30 Economy and Socief' 433-66; Joseph Suglitz, meanwhile, argues that even efficient markets may not be Pareto optimal: J E Stiglitz, "Pareto optimaliy and compecition" (1981) 36 Journal of Finance 235-51; futhermore, G A Cohen highlights that justice-based arguments for incqualities-as-incentives simply do not hold as normative statements: G Cohen, Rescuing Justice and Equality (Cambridge NLA: Harvard UP 2008). They may be of pragmatuc consequence but only in the context of already existing injustices relating to redistribution in societ:

40 See S Kaplan and J Rauh, "Wall Street and Main Street: what contributes to the rise in the highest incomes?", paper presented at the American Finance Association 2008 New Orleans Mectings.

41 A Johnston, "After the OFR: can UK shareholder value still be enlightened?" (20106) 7 European Business Organiquation Las Revien' 836-37; see also I Anabtaui, "Some skepticism about increasing sharcholder power", Law and Ieconomics Rescarch Paper Series, Research Paper No. 05-16 (Los Angeles: School of Lau; University of California 2005): moreover, there is no defintive matrix for judging the divergent demands of institutional sharcholders. Pressure from one set of institutional sharcholders may disadvantage others. See I Anabtaui and L stout, "Fiduciary dutics for actuvist shareholders" (2008) 60 Stanford Law Review 1255-309. 
per cent in 2007, up from 40 per cent in 1990.42 This indicates that the mean stock holding period on the exchange has fallen to "substantially less than 1 year". ${ }^{43}$ Similarly, the annual turnover of shares on the New York Stock Exchange went from 12 per cent in 1960 to 102 per cent in $2005 .^{44}$ With each transaction, remember, comes an accumulation of fees.

Further to this, we must remember that institutional investors suffer from the same agency problems that they're supposed to solve. The only difference as we move up the chain through pension funds and the like is that the information disadvantages of ostensible principals vis-à-vis their agents are even more glaring. Incentives for agents to work on their clients'/principals' behalf would only work in the presence of a coherent and accessible market for financial services. But there is no market. People lack the information to choose between pension or savings products. Or, more starkly, if their savings come straight out of wages through workplace schemes, then any link berween demand and performance may all but break. Given that many people do not use their savings in this manner out of entrepreneurial or enterprising ambitions, but because the devaluation of other alternatives (pensions funded by taxation for instance) ${ }^{45}$ has left them with little in the way of choice, it is difficult to expect that they devote their energy to performing oversight over their agents in distant and impermeable financial markets.

Finally, as events in the past decade have shown, rather than unleashing enterprise or improving the lot of the individual, the financialisation of savings has transferred substantial risk to the individual. With increasingly volatile portfolios in decline at many points in the last decade, contributors to pension funds are essentially forced to bet on the health of the markets at their point of retirement. Rather than being focused on shareholder value, the rise of the shareholding democracy has simply delivered greater appropriation by managers and financial intermediaries, a massive transfer of risk to individuals and a regressive redistribution to the wealthier members of society:

Again, as with ownership claims, co-opting convention norms about democracy into the legitimation of shareholder value is normatively and empirically untenable. The company, by these terms, is not an accountability vehicle in any conventional sense at all.

\section{EFFICIENCY ARGUMENTS}

Once we dispense with the democratic/egalitarian argument, it becomes difficult to regard any efficiency arguments as having any particular force. Nevertheless, the attachment to the social benefits of efficiency is prevalent in the literature. ${ }^{46}$ While efficiency can have no normative force in and of itself, it is an important component in general Hayekian schema for the market: that blockholding interests will be driven out in favour of more productive parties. Benefits to all stakeholders and even general social welfare will follow. Efficiency is

42 World Federation of Exchanges, Turnoter l'elocity of Domestic Shares Statistics (Paris: World Federation of Exchanges 2007); see also table in A Pendleton and H F Gospel, "Markets and relationships: finance, governance and labour in the United Kingdom" in H F Gospel and A Pendleton (eds), Corporate Governance and Labour Management (Oxford: OUP 2005), p. 73.

43 D Walker, Guidelines for Disclosure and Transparengy in Private Equity (the Walker Report) (London: British Venture Capital Association 2007), p. 10.

44 T Clarke, International Corporate Governance: A comparative approach (London: Routledge 2007). p. 238.

45 Ireland, "Shareholder primacy", n. 35 above, p. 53.

46 Agency theory is based on an efficiency model-based description of the company. Sice Fama and Junsen. "Scparation", n. 22 above; Fama and Jensen, "Agency problems", n. 23 above; M C Jensen and II H Meckling, "Theory of the firm: managerial behavior, agency costs and ounership structure" (1976) 3 Journal Of Finamial Economics 305-60; M C Jensen, "Value maximization, stakeholder theory, and the corporate objective function" (2001) 14 Journal of Applied Corporate Fimulic; Easterbrook and Fischel, Economic Siruture, n. 22 above; K Eiscnhardt, "igency theory: an assessment and review" (1989) 14. Academy' of Management Revresw 57-74. 
the core principle driving the shareholder value paradigm in corporate governance and is held to be the core driver of company law. Moreover, the purported efficiency of the shareholder value paradigm is regarded as one of the strong forces behind any convergence on shareholder value: more efficient companies and regimes will drive the less efficient ones out of the game. ${ }^{47}$

The problem with the efficiency argument is that it is very difficult to formulate an evidence basis for a claim that a particular economic system or system of governance is more or less efficient than any other. ${ }^{48}$ While it is possible to identify individual inefficiencies as they arise it is not possible to come up with a systematic sense of efficiency beyond a general assertion that it is a necessary consequence of unfettered markets. First off, the link between shareholder value and efficiency is tautological: efficiency is described as anything that delivers shareholder value while shareholder value is legitimated on the grounds that it is efficient.

It is not clear at any point what precisely shareholder value might entail. All shareholders may not have entirely common interests or motives. ${ }^{49}$ At the very least they may define share values as counting over different time scales. It is unclear that shareholder value actually does provide a clearer and more transparent incentive upon which directors might build their strategies for the firm and it is certainly difficult to sustain the idea that attending to shareholder value is superior because "shareholder value is a single-valued metric that is also observable and measurable". ${ }^{50}$ It is not necessarily a single value and observation and measurement do not float free of decisions as to what strategies will count as enhancing shareholder value. So, while a multi-stakeholder approach may well "permit managers and directors to serve no one but themselves," 51 it is not clear that a shareholderorientation will do any better.

How, indeed, can strategies designed to enhance shareholder value actually do so in any obvious way? The development of management consultancy-driven shareholder valueoriented reforms in corporations, while heavy on rhetoric, have tended to be rather light on actual reform. Rather, once we push past the construction of new forms of story to tell market actors, shareholder value strategies appear to be little more than "a good deal of tautology combined with a fairly traditional 1980s concept of strategy".52 What the shareholder value rhetoric is good at, however, is the production of short-term bounces as firms are seen to be intensifying their focus on shareholder value through the ostentatious adoption of new strategies or, indeed, new boards and CEOs. ${ }^{33}$

Whose efficiency ought we to privilege? As Williams points out, drawing from Lazonick and O'Sullivan, through the 1970 s, "most US corporations retained and reinvested earnings which provided the economic dynamic behind broadly based prosperity". Since the 1980 s,

47 Hansmann and Kraakman, "The end of history", n. 6 above, p. 442; $\triangle$ Keay, "Ascertaining the corporate objective: an entty maximisation and sustainability model" (2008) 71 Modern Law Review 668.

48 Sce R Ball, "What do we know about stock market 'efficiency"?, unpublished manuscript (University of Rochester: William E Simon Graduate School of Business Administration, Managenal Economics Research Center 1989).

49 Keav, "Ascertaining the corporate objective", 11. 47 above, p. 670; e.g. on possible conflicts between instututional and other investors, see T W'oidtke, "Agents watching agents? Evidence from pension fund ownership and firm value" (2002) 63 Journal of Financial Economics 99-131; Anabtawi, "Some skepticism",
"1. 41 above.

50 Sundaram and Inkpen, "The corporate objective tevisited", 11. 23 above, p. 355.

51 Maccy, "Economic analysis", n. 23 above, p. 36.

52 liroud et al., Financialization and Strateg)', u. + abov'c, p. 47.

53 For one story' of a market spectacle-driven search for new leadership, sec R khurana, Searthing for " Corporate Savior: The irrational quest for charismanc CEOs (Pnnceton NJ: Pnnceton UP 2002), pp. 1-19. 
however, "there has been a 'transformation of US corporate strategy' around the principles of downsizing the corporate labour-force and distributing earnings to shareholders". 54 Why, rather than adopting an efficiency rule where directors would "maximize the sum of all the risk-adjusted returns enjoyed by all of the groups that participate in firms", 55 would shareholder value be privileged? Part of the answer must lie in the fact that shareholder value is not an efficiency maxim at all. Rather, it is a "a power relationship, that is a particular (societal) way to design a corporation". ${ }^{6}$ Convergence on shareholder value is not a matter of convergence on efficiency. Claims about accountability are about these relationships, not about formal processes of agent-control. It is a set of political decisions as to how resources ought to be distributed in society. It is riven with value judgments and decisions, masquerading as neutral forces. ${ }^{57}$

\section{FinANCIALISATION AND FINANCIAL CRISES}

The three defences of shareholder value are worth taking seriously, given that they provide the backdrop to economic life in corporate economies. Moreover, they bring a focus on what precisely is meant in political and business parlance by corporate accountability. Nevertheless, they are neither empirically nor normatively sustainable in and of themselves. The normative dimension is in many ways the most important, given that accountability claims have always involved the construction of normative frames within which people ought to work. That is, the appeal to accountability is never merely a matter of brute force nor a matter of simple expediency. It is a plea for a certain claim to power over (in this case) the company to be honoured by society at large. Or, to put it differently, accountability is a "second-person standpoint", that occurs within and helps sustain or transform a moral community. ${ }^{58}$

Furthermore, we have to understand the manner in which the shareholder value claim, and myriad specific claims that follow from it, has sought to reconfigure the moral community in line with the opportunities provided by the technical and regulatory innovations behind the financialisation of corporate economies and corporate governance. It goes without saying that managerial appropriation is scarcely new: As Lawrence Mitchell and Paddy Ireland point out, large industrial corporations, in both the United Kingdom and the United States, originated in large part from the desire of proposers to extract investment and speculative capital from a growing class of investors. Industry, in these terms, is carried on, not for the sake of production, but "for the sake of business", 59 or, to be more precise, the business of market accumulation.

Primary among the features of financialised capitalism is the hyper-innovative character of the markets, driven by "the growth in the liquidity of capital markets, expressing increases in the breakdown and transfer of risks", and by "the upsurge, in these same markets, of

54 Williams, "From shareholder value", n. + above, pp. 3-4.

55 Stout, "Bad and not-so-bad", n. 8 above, p. 1198.

56 A Rebérioux, "European style of corporate governance at the crossroads" (2002) 40 Journal of Common Market Sindies 119.

57 See G M Frankfurter and E G McGoun, "Ideology and the theory of financial economics" (1999) 39 Journul of Economic Behavior cir Organization 159-77.

58 See Darwall, The Second-person Standpoint, n. 3 above; C O'Kelly, "I political theory of accountability" in M Dubnick and H G Frederickson (eds), Accountability and its Promises (New York: M E Sharpe 2009).

59 Mitchell, The Spechlation Economy, n. 19 above, p. 13; Ireland, "Capitalism", n. 18 above; P Ireland, "History, critical legal studies and the mysterious disappearance of capitalism" (2003) 65 Modern Law Reizew 106-19; Ireland, "Company law", 11. 25 above. 
investment funds, responsible for the management of continually increasing savings" 60 and, finally, the "mass-marketing of financial products to consumers" " ${ }^{61}$ Financialised capitalism, "oozing with instability", ${ }^{2} 2$ has not seen the democratisation of capital but the capitalisation of savings through institutional investors, driving a systematic reliance "on the constant searching out, or the construction of, new asset streams, usually through a process of aggregation, which then - and only then - allows speculation to take place". ${ }^{63}$

This hyper-innovative system is combined with the enlisting of internal and external gatekeepers and financial intermediaries through a dense network of fees and bonuses. While these are designed to incentivise individual behaviour, massive hazards emerge in terms of risks that resources would be appropriated as everyone is brought inside the financial flow. The norions upon which agency theory is based - gatekeeping, governance and private regulation - all break down. ${ }^{64}$ Instead, innovation takes on a life of its own when intermediaries develop "a stake in an economy of permanent restructuring", beyond the production of value "because deals (be it acquisition or demerger, new issues or buybacks, securitization or rebundling risks) are the source of fees". ${ }^{65}$ In fact, the amounts of money circulating through financial and equity markets far exceeds those circulating through the "real" economy. 66

\section{Enron}

Enron holds a totemic place in the development of this process. Enron was, in hindsight, the quintessential financialised company of the new millennium. Enron's self-consumption occurred in the midst of an incredibly complicated set of financial arrangements as the company first attempted literally to transform itself into a set of markets and then as managers, with lucrative collaboration from gatekeepers, ${ }^{67}$ set about appropriating the company's resources. The key to Enron's success was that it could financialise infrastructural products like electricity, gas or broadband. By constructing market instruments in these products, Enron hoped to collect at both ends, so to speak. The company would not only trade in the products, but would collect a fee for each trade that third parties made on their market. Enron's executives were aggressive in their pursuit of relationships with auditors, ratings agencies and banks, all of whom made vast profits from

60 Aglietta and Rebénoux, Corporate Gorernance Adrift, n. 4 above, p. 1: See Froud et al., "New actors", n. 4 above, pp. 339-40; A J,cyshon and N Thrift, "The capitalization of almost everything" (2007) 24 Theory, Culture c Societr, $97-115$.

61 Froud et al., "New actors", n. 4 above, p. 340.

62 Aglictta and Rebérioux, Corporate Governance Adrift, n. 4 above, p. 183.

63 See also I.eyshon and Thrift, "The capitalization", n. 60 above, p. 98; the risks of financialisation were pointed to as early as the mid-1980s by the Committee on the Global Financial System, Recent Innovations in International Banking (The Cross Report) (Geneva: Bank for Internatonal Settlements, CGFS Publications 1986), PP. 187ff.

64 See J Coffee, Gatekeepers: The professions and corporate governance (Oxford: OUP 2006).

65 P Folkman, J Froud, 5 Johal and $\mathrm{K}$ Williams, "Working for themselves? Capital market intermediaries and present day capitalusm" (2007) 49 Business History 561; On compensation packages, scc P Bolton, J Scheinkma and W Xiong, "Executive compensation and short-termist behaviour in speculative markets" (2006) 73 Review of Economic Studies 577-610.

66 R Dore, "Financializauon of the global cconomy" (2008) 17 Industrial and Corporate Cbange 1097-112.

67 Indeed, Andcrson, Entun's auditor, made millions from consulancy services armed at assisting Enron's managers construct the sham special vehicles that Anderson ought to have exposed in the audit. See W' Bratton, "Enton and the dark side of shareholder value" (2002) 76 Twlane Law Review 1350. 
the provision of non-audit services, ratings on financial products and the construction of Byzantine financial manoeuvres. Its collapse followed as managers took reckless risks and strove to obscure huge losses as various speculative ventures went badly wrong. ${ }^{68}$

While the manner of Enron's death was ultimately conventional in many ways, in that the company added a variety of bad bets to existing bad debts, ${ }^{69}$ the cause of its death lay with the sequence of financial bets that Enron made, the linking of its stock market value to its financialised products and, to a lesser extent, the appropriation of company assets by directors. Moreover, the directors' activities could not have been possible without gatekeepers' collaboration, itself facilitated by a network of fees and bonuses. Enron's directors, when the company was apparently successful, were aggressive in their manipulation of financial disclosure so as to present the most advantageous returns to the stock market. This in turn allowed the markets spectacularly to overvalue the company.

The political and media narratives at the time were that the Enron collapse was down to a need to make companies more "accountable to shareholders". However, this begs the question of whether Enron's capacity to get away with the confection of success it created was more a result of managers obscuring information or of many shareholders not being motivated to question that information in the first place? On the one hand, "one thing that did contribute", to the company's collapse "was Enron's willing embrace of the favorite governance 'reform' fad of the 1990 s, stock options". ${ }^{70}$ In one sense, Enron collapsed in an era when shareholders were already the focus. The problem was that that focus was simply a vehicle for appropriation on the part of the directors. The proper incentives were also perverse incentives.

Added to that, a concern for actual performance only matters to long-term investors if they either cannot exit or will not exit (in the case of people or institutions whose shareholding is motivated by considerations other than market values). In other cases, when the share is not treated as a fact of ownership but as a tradeable commodity and where the stakes in companies do not go beyond the sentiment of market players, a corporation's reputation for success will continue until the point when uncritical sentiments about the stock, driving bids higher and higher, are replaced by deflation as demand slumps and those at the top of the pyramid are left with losses. The important thing for the investor is not to be the left carrying the can when the slump hits.

It seems, however, that the Enron and other collapses in 2001-02 were harbingers of

68 Bratton, "Enron", n. 67 above; H Butler and L Ribstein, The Sarbanes-Oxley Debacle: How to fix it and what we ive learned (Washington DC: American Enterprise Institute 2006); S Deakin and S Konzelmann, "Learning from Enron" (2004) 12 Corporate Governance: An international review 134-42; J Gordon, "What Enron means for the managernent and control of the modern business corporation: some initial reflections" (2002) 69 University of Chicago Law Review 1233-50; P M Healy and K G Palepu, "The fall of Enron" (2003) 17 Journal of Economic Perspectives 3-26; D Kershaw, "Waitang for Enron: the unstable equilibrium of auditor independence regulation" (2006) 33 Journal of Law and Society 388-420; M Klock, "Two possible answers to the Enron experience: will it be regulation of fortune tellers or rebirth of secondary liability?" (2002) 28 Jourmal of Corporation Law 69-109; Coffee, Gatekeepers, n. 64 above; for a series of journalistic accounts, see B Cruver, Enron: Anatomy of greed - the unshredded truth from an Enron insider new edn (London: Irrow Books 2003); P Elkind and B Mclean, The Smartest Gry's in the Room: The amaqing rise and scandalous fall of Enron new edn (Harmondsworth: Penguin 2004); P C Fusaro and R Miller, Wrbat Went W"rong at Enron (Chichester: John Wiley \& Sons 2002); see also special issues on Enron in "Symposium: Enron" (2002) 35 Connectiout Lan" Reiven" 915-1254: "Symposium: lessons from Enron, how did corporate and securities law fail" (2003) 48 I i/lmom Law Revien 989-1280.

69 D Langevoort, "The organizational psychologv of hyper-competition: corporate irtesponsibility and the lessons of Enron" (2002) 70 George II"ashington Law Review 974.

70 Stout, "The mythical benefits", 11. 15 above, p. 808 . 
the greater crisis that hit Anglo-American capitalism in 2007. While immediately caused by a property bubble, and thus fitting in with a long line of financial crashes, ${ }^{71}$ as I said in the introduction, the financial crisis was down to corporate governance: to structures endogenous to the corporate form itself. The range of incentives available to executives and to intermediaries and the ceding of oversight power to financial markets led to the pursuit of highly risky but spectacular products that, through the externalising of risk, produced illusory liquidity for the financial services sector. The problem was not about bad decisions in and of themselves. It was about the development of a system that required bad decisions. To pursue the safe path would have been to lose favour with the markets and, ultimately, to lose one's position. In these circumstances, financialisation means that the founding conflict between principals and agents, upon which agency theory is based, simply disappears.

While "the tradability of securities and the liquidity of markets allow firms to escape the sphere of ownership", 72 the share has been placed in a pre-eminent position in corporate governance. This shift has led to the birth of what might be called the postmodern corporate form, where totemic information takes the form of news that will lead to positive share movements. Increasingly volatile markets are as prone to spectacles, such as the introduction of new CEOs or innovative though risky financial investments that exploit "stock market crazes", 73 as they are to actual production. Moreover, market actors have relied on, or simulate a reliance on, verification from gatekeepers that are themselves deeply implicated in the fees structures surrounding new products.

While it is possible that share price movements might be related to increases in production or revenue or profit, it is by no means necessary that this would be the case. Information might be produced through corporate governance reform, but it might just as well be produced through reforms to the means by which information is conveyed, by focusing on the short-term to the detriment of long-term value creation, or simply by paying homage to the important norms of shareholder value. These all involve management of shares rather than of companies in the sense that the corporation is reconfigured so that its function is the production of information for dissemination to stock markets.

\section{Conclusion: back to accountability}

It would also be wrong to say that the corporate economy and the corporate form has been entirely unsuccessful in reconfiguring moral communities around shareholder value, at least when it comes to the community of corporate and economic elites. The key has been for the discourse of this community to be extended and accepted in society at large. In these terms, the most important role of shareholder value in the context of financialisation and the postmodern company has been to expand the influence of the shareholder value story beyond the moral sub-community within which it might best resonate. The accountability story at the root of shareholder value has also been very successful in insulating the company from external scrutiny and control. The processes and procedures put in place, while expanding the sphere of accountability, and while displaying more publicity than has ever existed before in economic vehicles, has actually served to close down external scrutiny, both by giving the appearance of a self-regulatory system (and thus an argument against external regulation) and by actually obscuring wrongdoing. ${ }^{74}$ Accountability, in these terms,

71 As described by Kindleberger and Aliber, Mamias, Pamics and Crasbes, n. 1 above.

72 Aglecta and Reberioux, Corporate Govername Adrift, n. 4 above, p. $26+$.

73 lbid., p. 97.

74 For a discussion of thesc penls in accountability, sec R Mulgan, "'. Iccountability': an ever-expanding concept?" (2000) 78 Public Administration 555-73. 
is less about delegated control and more about the struggle to both dominate a social (in this case corporate) sphere and to insulate it from other stakeholders.

Claims about accountability are, in these circumstances, claims about politics. They are claims about the terms of virtue in a given society: how that society ought to be organised. When appeals are made to the wider norms of moral communities, the normative core of an accountability discourse is rendered testable. Normative claims are made in the form of empirical claims.

My aim in this paper is not to argue that the shareholder value paradigm as a rallying point for corporate governance is at an end. As Brian Cheffins has pointed out regarding the UK's legal structures, it is very likely here to stay. ${ }^{75}$ What has changed, however, is the idea of sharcholder value as a defensible ideal for corporate governance, at least in the context of wider social norms. Shareholder value is now a convention in search of a justification as the fiction of rational market efficiency dies a death that has turned out to be painful far beyond the boundaries of the company. 